\title{
Polyethylene Low and High Density-Polyethylene Terephthalate and Polypropylene Blend as Matrices for Wood Flour - Plastic Composites
}

\author{
Jonathan GUIDIGO ${ }^{1}$, Stéphane MOLINA ${ }^{2}$, Edmond C. ADJOVI $^{3}$, André MERLIN ${ }^{4}$, DONNOT André5, \\ Merlin SIMO TAGNE
}

${ }^{1}$ Laboratory for study and research on wood material (LERMAB), 54506 Vandœuvre lès Nancy Cedex - France $\mathrm{PhD}$ student at the University of Lorraine (France) and the university of Abomey-Calavi(Benin)

\begin{abstract}
${ }^{2}$ Laboratory for study and research on wood material (LERMAB), 54506 Vandœuvre lès Nancy Cedex - France Researcher at the university of Lorraine (France).
\end{abstract}

\author{
${ }^{3}$ C. Edmond ADJOVI, Laboratory of Energetic and Applied Mechanics (LEMA), EPAC 01 BP 2009 Cotonou, University of Abomey- \\ Calavi, (Benin).
}

${ }^{4}$ Laboratory for study and research on wood material (LERMAB), 54506 Vandœuvre lès Nancy Cedex - France Researcher at the university of Lorraine (France).

${ }^{5}$ Laboratory for study and research on wood material (LERMAB), 54506 Vandœuvre lès Nancy Cedex - France Researcher at the university of Lorraine (France).

\author{
${ }^{6}$ Laboratory for study and research on wood material (LERMAB), 88026 Epinal Cedex France \\ Post Doctoral Position, University of Lorraine, LERMAB, Epinal-France
}

\begin{abstract}
This study present a composite material made of four thermoplastic polymers and wood sawdust. The wood sawdust of size 630, 315, $160 \mu \mathrm{m}$ and plastic waste containing 3,91\% of polyethylene terephthalate (PET), 87,62\% of High-density polyethylene (HDPE), 7,23\% of Low-density polyethylene (LDPE) and $1.21 \%$ of Polypropylene (PP) have been transformed in composites wood/polymer by extrusion. The mechanical and thermal properties have been studied through tensile test and a thermogravimetric analysis. The weight ratio of the cellulosic materials to polymer matrix was 25:75(w:w). Morphological study was done on the rupture surface on samples to appreciate the adherence of wood sawdust/matrix. The study shows that the presence of the wood sawdust increases the modulus of elasticity (MOE) of the composite by conferring a better rigidity. Also, we see that wood sawdust increases the thermal stability of the composite.
\end{abstract}

Keywords: Tensile test, Composite wood polymer, Wood sawdust, Thermogravimetric analysis

\section{Introduction}

The environment protection and optimal management of natural resources for a sustainable development are most important concerns today. In Africa the management of plastic waste and wood sawdust is a real concern for the municipalities. Indeed the inexistence of management policy exposes the urban populations to garbage dumps containing plastics and wood chips. This situation creates a public health issues. The survival of human being is affected by this situation [1] [2] [3]. A study made in Benin Republic has shown that $86 \%$ of plastic users throw them in the street after usage, $5.5 \%$ incinerate them, $5.5 \%$ use them as combustible, and $2.75 \%$ for other usages [4]. In 2012, the total amount of plastic waste produced was 12,026 tons [4]. The waste management is a real challenge for local authorities and researchers [5] [6] [7] [8] [9] [10].

The household wastes of the cotonou city (Benin) contain $3.8 \%$ of PET, $84.99 \%$ of HDPE, $7.0 \%$ of LDPE, $1.18 \%$ of PP and $3.01 \%$ of PUR [4].Analysis of these polymers showed that different types of Polymers find themselves on the same heap [4]. Indeed for a recycling purpose of these polymers it is technically difficult and expensive to separate these mixtures of plastic [11] [12]. The performances of these mixtures are usually much lower than the single elements because the polymers are immiscible [13].

The specificity of this work consists in realizing a composite wood / polymers material by using PET / HDPE / LDPE / PP / wood sawdust. The goal of this study is to find some mechanical properties that are close to the literature. Indeed many published works on the Wood Polymer Composite (WPC) present some values in the range of $1000-2000 \mathrm{MPa}$ for the elasticity modulus and $20-30 \mathrm{MPa}$ for the tensile rupture modulus in for the wood flour in the range of $20 \%$ $25 \%[12,14,15,16,17,18,19,20]$.

\section{Materials and Methods}

\subsection{Materials}

\subsubsection{The matrix}

The polymer matrix used is a mixture of PP, HDPE, LDPE and PET. These different polymers come from recycling and come from good fellow certified ISO 9001 in France. The physical characteristics of these polymers are shown in

\section{Volume 6 Issue 1, January 2017




\section{International Journal of Science and Research (IJSR)}

ISSN (Online): 2319-7064

Index Copernicus Value (2015): 78.96 | Impact Factor (2015): 6.391

Table 1.

Table 1: Physical and mechanical characteristics of some thermoplastic polymers [21]

\begin{tabular}{|c|c|c|c|}
\hline Polymers & Density $\left(\mathrm{g} \cdot \mathrm{cm}^{3}\right)$ & $\sigma_{\text {tensile }}(\mathrm{MPa})$ & $\begin{array}{c}\mathrm{MOE} \\
(\mathrm{GPa})\end{array}$ \\
\hline PP & 0,9 & $25-40$ & $0,9-1,5$ \\
\hline HDPE & 0,95 & $15-40$ & $0,5-1,2$ \\
\hline LDPE & 0,92 & $5-25$ & $0,1-0,3$ \\
\hline PET & $1,3-1,4$ & 80 & $2-4$ \\
\hline PS & 1,05 & $30-100$ & $2,3-4,1$ \\
\hline
\end{tabular}

\subsubsection{The wood flour}

The essence of the wood flour that was used in our study is abzeria essence (afzélia Africana). the wood flour was collected in sawmills and was sieved to separate the material into several granular classes. Finely ground wood flour comes from woody material recovered as a result of planning and sawing operations. The physical properties (Table 2) of wood flour: absolute density, apparent density and humidity level vary relatively for the same gasoline and depending on the place of collection. At the end of the sieving, we separated the sawdust by diameter. Thus, three diameters of sawdust and two granular mixtures were studied. We have therefore used the diameters $0.315 \mathrm{~mm}$ $0.160 \mathrm{~mm}-0.08 \mathrm{~mm}$ (Figure 1.)

Table 2: Physical properties of wood flour by size.

\begin{tabular}{|c|c|c|c|}
\hline $\begin{array}{c}\text { Size of wood } \\
\text { flour }(\mathrm{mm})\end{array}$ & $\begin{array}{c}\text { Absolute } \\
\text { density }\left(\mathrm{g} / \mathrm{cm}^{3}\right)\end{array}$ & $\begin{array}{c}\text { Apparent } \\
\text { density }\left(\mathrm{g} / \mathrm{cm}^{3}\right)\end{array}$ & $\begin{array}{c}\text { Humidity } \\
\text { level }(\%)\end{array}$ \\
\hline $0,630 \mathrm{~mm}$ & $0,270 \pm 0,0082$ & $0,126 \pm 0,005$ & $10,79 \pm 1,16$ \\
\hline $0,315 \mathrm{~mm}$ & $0,278 \pm 0,0072$ & $0,161 \pm 0,008$ & $11,51 \pm 1,12$ \\
\hline $0,160 \mathrm{~mm}$ & $0,294 \pm 0,0078$ & $0,171 \pm 0,002$ & $0,07 \pm 0,87$ \\
\hline
\end{tabular}

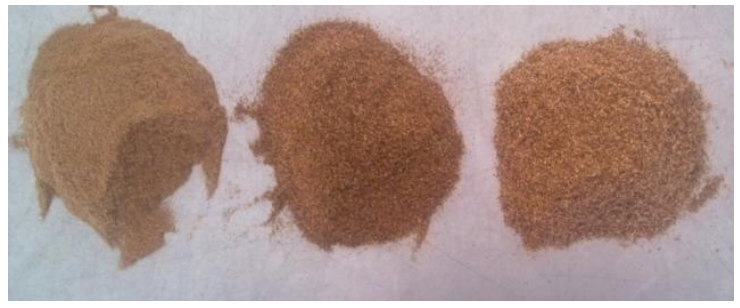

Figure 1 : Wood flour by size

\subsection{Composite preparation}

The extruder used for the manufacture of the wood polymers composite (CBP) allows the introduction of a limited

Table 3). These results are close to the tensile resistance of HDPE used. Osso researches conducted by Bailon and Morin [25] [26] gives a elasticity modulus (MOE) of approximately $1000 \mathrm{MPa}$ and a rupture modulus (MOR) between 21 and $38 \mathrm{MPa}$. It turns out that the combination of the different polymers that leads to the E-CTN do not have significant influence on the MOE, MOR and HDPE in tensile test although the polymers are immiscible. quantity of wood sawdust to facilitate it's mechanical running. Therefore it turns out that many authors use the wood fibre between 10 and $35 \%$ [22] [23] [24].all the composite were made from $25 \%$ sawdust and $75 \%$ thermoplastic matrix to facilitate the enrobing of the wood particles by the plastic matrix. The different polymers have been mixed with wood flour. It is important that the mixture is homogeneous before being introduced into the extruder. The consequence would be highly heterogeneous material with regard to the sawdust and polymer repartition. The extruder was controlled at $175^{\circ} \mathrm{C}, 185^{\circ} \mathrm{C}, 195^{\circ} \mathrm{C}$ and $200^{\circ} \mathrm{C}$ for zones 1, 2, 3 and 4 respectively, while the temperature of the die was held at $200{ }^{\circ} \mathrm{C}$. The melt temperature was kept $200{ }^{\circ} \mathrm{C}$ to prevent wood degradation . The extruded mixture is put under pressure in a moule preheated at $170^{\circ} \mathrm{C}$ and screwed at the output of the extruder. The demolding is done 3 hours later

\subsection{Tensile test}

The tensile test have been done at ambient temperature by using a INSTRION 4467 model which is a tensile test machine with respect to the norm NF EN ISO 527-1 and NF EN ISO 527-2 on wood/polymer samples

\subsection{Thermogravimetric test}

The thermogravimetric analysis has been done by using the SETRAN thermal analyser at a heating speed of $2 \mathrm{~K}$ per minute under azoth atmosphere of $20 \mathrm{ml} / \mathrm{min}$. A sample made of $80 \mathrm{mg}$ composite material and a sample made of 70 mg wood sawdust is used for the present analysis.

\subsection{Morphological study}

The morphological properties of samples have been analysed by using the HITACHI TM-3000 electronic microscope. After the tensile test, the rupture surface of the samples is taken and observed under the electronic microscope.

\section{Results and Discussion}

\subsection{Tensile properties}

The plastic matrix of reference E-CTN is made of $87.62 \%$ of HDPE and the polymers listed in

Table 3. The tensile resistance is $24.48 \mathrm{MPa}$ and the elasticity modulus $975.2 \mathrm{MPa}$ (see

By considering the MOR in tensile test it turns out that for wood flour of 630,315 and $160 \mu \mathrm{m}$ diameters the MOR lowly vary. One can therefore notice that the MOR rises when the size of the wood sawdust decrease [27]. One can also notice a slight decreasing of the MOR of the composite with respect the MOR of the matrix. When the form factor is lower than 10, the fibres behave like loads [28] [29]. In addition, the presence of cellulosic elements improves the tensile MOE. The CBP are then more rigid than the polymer matrix [30]. The observed values of the MOE are close to the one obtained by Klason et al [31] for a composite with a HDPE matrix.

\section{Volume 6 Issue 1, January 2017 www.ijsr.net}




\section{International Journal of Science and Research (IJSR) \\ ISSN (Online): 2319-7064}

Index Copernicus Value (2015): 78.96 | Impact Factor (2015): 6.391

Table 3: Mechanical results of wood / polymer composites and thermoplastic matrix

\begin{tabular}{|c|c|c|c|c|c|c|c|}
\hline CODE & $\begin{array}{c}\text { HDPE } \\
\%\end{array}$ & $\begin{array}{c}\text { LDPE } \\
\%\end{array}$ & $\begin{array}{c}\text { PET } \\
\%\end{array}$ & $\begin{array}{c}\text { PP } \\
\%\end{array}$ & Fiber $\mu \mathrm{m}$ & MOR(MPa) & MOE(MPa) \\
\hline Matrix & & & & & & & \\
\hline E-CTN & 87,62 & 7,23 & 3,91 & 1,21 & 0 & $24,48 \pm 0,34$ & $975,20 \pm 20,2$ \\
\hline Composite & & & & & & & \\
\hline 3E-CTN630 & 87,62 & 7,23 & 3,91 & 1,21 & 630 & $21,79 \pm 0,99$ & $1341,85 \pm 81,82$ \\
\hline 3E-CTN315 & 87,62 & 7,23 & 3,91 & 1,21 & 315 & $21,86 \pm 0,73$ & $1391,19 \pm 90,59$ \\
\hline 3E-CTN160 & 87,62 & 7,23 & 3,91 & 1,21 & 160 & $22,40 \pm 0,58$ & $1578,80 \pm 67,23$ \\
\hline
\end{tabular}
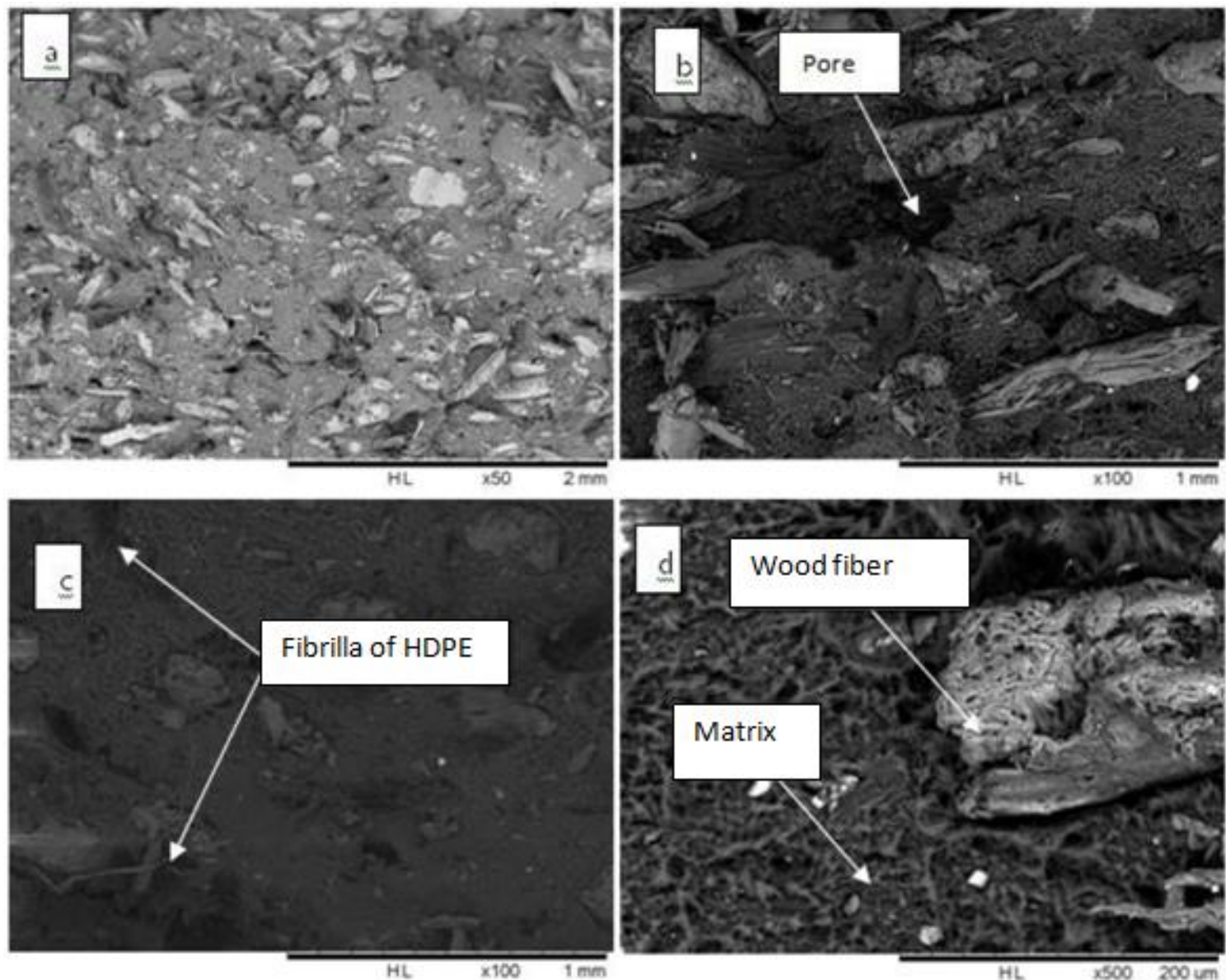

Figure 2 : SEM micrographs of fracture surfaces of the composites

\subsection{Morphological properties}

The SEM image of Fig. 3. represents the microstructure of the specimen on a rupture facies at the end of a one-axial tensile test. Although the matrix is obtained from several polymers, coherence at the level of the molecules constituting it is generally observed (Fig.3.a) This uniformity observed at the level of the matrix is confirmed on a larger scale x100 on the images Fig.3.b and Fig. 3.c. After fracture, we see in the image $\mathrm{c}$ what could be HDPE fibrils that correspond to stretched macromolecules that connect small crystal blocks to strong deformations [32]. The fibrils are conventionally observed in this kind of HDPE-based composite, are randomly oriented in the three directions of the space and have an average size of the order of one micron. In addition, this microstructure reveals broken wood fibers. The presence of these broken wood fibers indicates a break in the wood and not at the woodmatrix interface. This observation confirms the good mechanical strength of the wood-resin interface according to the observations usually encountered in wood-plastic composites [33]. In the image a the wood fibers are not oriented in the direction of traction; Indicating good adhesion of the wood / matrix interface. However, in some places, the fibers of wood are loosened, leaving a hole in the fracture rupture.

\subsection{Thermal Properties}

The thermal stability of composites is a very important parameter for the processing and use of these materials. The making such composites require the mixing of the fibers and the matrix at high temperatures, so that the degradation of the cellulosic materials can produce adverse effects on

\section{Volume 6 Issue 1, January 2017 www.ijsr.net}




\section{International Journal of Science and Research (IJSR) \\ ISSN (Online): 2319-7064}

Index Copernicus Value (2015): 78.96 | Impact Factor (2015): 6.391

properties. The results of thermogravimetric analysis (TGA) are consistent with those of the literature [34]. There are three stages of degradation (Fig. 4):

1) The first is linked to the release of water [35] [36] [37]; the second is related to the degradation of cellulosic substances, such as hemicellulose and cellulose [35];

2) The last step refers to the degradation of non-cellulosic substances at the highest temperatures [38].

The first loss of mass $(9 \%)$ between $270{ }^{\circ} \mathrm{C}$ and $345{ }^{\circ} \mathrm{C}$ corresponds to water loss and moisture content in wood fibers. The second loss of mass is the main one. At this stage, the composite loses $80 \%$ of its mass between $345{ }^{\circ} \mathrm{C}$ and $480{ }^{\circ} \mathrm{C}$. These include depolymerization of cellulose and breakage of glucosidic bonds, degradation of lignin and depolymerization of the matrix. There is also a slight displacement of about $25^{\circ} \mathrm{C}$ from the maximum degradation temperature to a higher temperature. The presence of the wood flour improves the thermal stability of the polymer matrix. The Fig. 5 shows that the TGA curves as a function of the size of the sawdust are superimposed. The size of the sawdust does not influence the thermal stability of the composite. Sawdust degrades from $200{ }^{\circ} \mathrm{C}$. The sawdust / polymer mixture must therefore be extruded at a temperature of less than $200^{\circ} \mathrm{C}$.

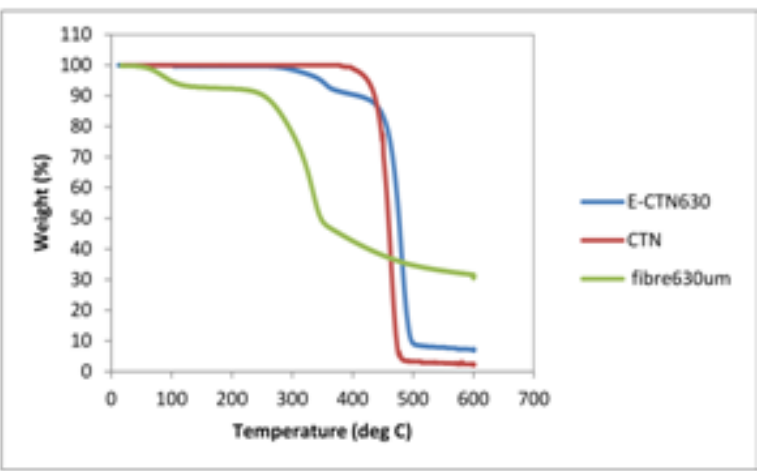

Figure 3 : TGA curves of the composites

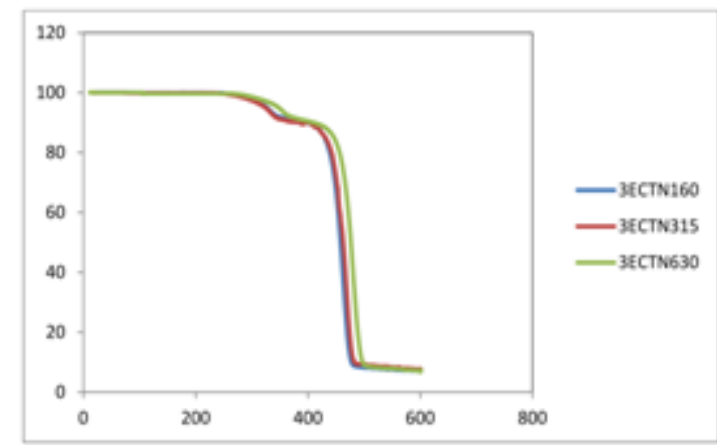

Figure 4 : TGA curves of the composites by wood flour size

\section{Conclusion}

The results of this work lead to the conclusion that:

1) The polymeric wood composite obtained from the ECTN matrix has mechanical properties similar to those of other authors [31] and promoting its use for applications.

2) Wood flour improves the rigidity of the polymer wood composite and does not significantly reduce the modulus of rupture.
3) The SEM study also shows good interfacial adhesion between the fibers and the matrix.

4) The presence of the wood flour improves the thermal stability of the polymer matrix.

\section{References}

[1] MEHU. Ministère de l'Environnement de l'Habitat et de l'Urbanisme du Bénin, Etude de faisabilité pour la valorisation des déchets plastiques au Bénin, Cotonou, 2002.

[2] V. Lawson, N. Liady and G. Boglo, Valorisation des déchets solides ménagers (DSM) au Benin: atouts et limites, Cotonou: Rapport d'étude pour DCAMBETHESDA, 2008, p. 63.

[3] A. GBEDO, Problématique de la valorisation des déchets plastiques à Cotonou, Cotonou: Thèse de Doctorat Université d'Abomey-Calavi, Faculté des Lettres Arts et Sciences Humaines, 2009, p. 237.

[4] RNCR. (Réseau National des Centres de Ressources), Etude sur la gestion des déchets plastiques dans l'espace UEMOA: cas du Bénin, Rapport final, 2011, p. 59.

[5] V. Francois, G. Feuillade, N. Skhiri, T. Lagier and G. Matejka, Indicating the Parameters of the State of Degradation of Municipal Solid Waste, vol. 2, Journal of Hazard-ous Materials B, 2006, pp. 1008-1015.

[6] T. Nikita, D. Mariane, F. Jacques, G. J. Roger and A. Taofiki, Characterization of Household Solid Waste in the Town of Abomey-Calavi in Benin, Cotonou: Journal of Environmental Protection, 2011, pp. 692699.

[7] A. A. Yemadje, P. Edorh, M. Aina, K. Gnandi, H. Christophe, B. Michel and T. Ulbad Polycarpe, Characterization of the household solid waste of the municipality of Abomey-Calavi in Benin, vol. 4, Journal of Environmental Research and Management, 2013.

[8] E. C. Adjovi, E. T. Olodo, F. Niang, D. Guitard, A. Foudjet and D. P. kamdem, Wood panels from sawdust and wasted plastic materials:Influence of the composition mixture on density and permeability, vol. 4, Cotonou: International Journal of Scientific \& Engineering Research, 2013.

[9] K. Melhyas, G. Pierre, A. Malahimi, F. Benoît and R. Yann, Thermal Degradation of Household Solid Waste in the Town of Abomey-Calavi in Benin: Kinetic Study, vol. 1, Waste and Biomass Valorization, 2016, pp. 5970.

[10]T. Cyrille, G. Patient, E. Patrick A and B. Michel, Collection and Characterization of Domestic Solid Waste in Cotonou, vol. 1, Cotonou: Environmental Application \& Science, 2014.

[11] U. LA, Commercial polymer blends, U. LA, Ed., Chapman and Hall, 1998.

[12]C. Clemons, Elastomer modified polypropylenepolyethylene blends as matrices for wood flour-plastic composites, Elsevier, Ed., Composites: Part A, 2010.

[13] U. LA, Polyethylene blends, U. LA, Ed., Chapman and Hall, 1998, p. 230-53.

[14] F.-V. Carmen, O.-M. Almudena, A.-A. Javier and G.-S. Carlos, Mechanical recycling and composition effects on the properties and structure of hardwood cellulose- 


\section{International Journal of Science and Research (IJSR) \\ ISSN (Online): 2319-7064 \\ Index Copernicus Value (2015): 78.96 | Impact Factor (2015): 6.391}

reinforced high density polyethylene eco-composites, Composites: Part A, 2015, p. 94-104.

[15]B. Witold, D. Tea, J. Peter and M. Harrison, Recycled HDPE reinforced with sol-gel silica modified wood sawdust, European Polymer Journal, 2016.

[16]A. Alireza, Wood-plastic composites as promising green-composites for automotive industries !, 99 ed., Tehran: Bioresource Technology, 2007, p. 4661-4667.

[17] R. Khandkar- Siddikur, I. Md Nazrul, R. Md Mushfiqur, H. Md Obaidullah, Islam, R. Md Mushfiqur, H. Md Obaidullah, D. Rudi and K. HPS Abdul, Flat-pressed wood plastic composites from sawdust and recycled polyethylene terephthalate (PET): physical and mechanical properties, vol. 2, SpringerPlus, 2013, pp. 2193-1801.

[18]A. Alireza and N. Amir, Performance properties of microcrystalline cellulose as a reinforcing agent in wood plastic composites, Composites: Part B, 2010, p. 578-581.

[19]Z. Hongli, Effect of a novel coupling agent, alkyl ketene dimer, on the mechanical properties of wood-plastic composites, 59 ed., Materials and Design, 2014, p. 130134.

[20] M. Sebastien, K. Ahmed, E. Fouad, C. Abdelkader, E. Karl and W. Michael P, Effects of processing method and fiber size on the structure and properties of woodplastic composites, vol. 40, Composites: Part A, 2009, p. $80-85$.

[21]J. Baïlon and J. Dorlot, Des matériaux,école Polytechnique de Montréal, troisième édition ed., Presses internationales Polytechniques, 2005.

[22] J. Julson, G. Subbarao, D. D. Stokke and H. H. Gieselman, Mechanical Properties of Biorenewable Fiber/Plastic Composites, J appl polym Sci, 2004, pp. 2484-2493.

[23] H. Chen, T. Chen and C. Hsu, Effects of Wood Particle Size and Mixing Ratios of HDPE on the Properties of the Composites, Holz als Roh- und Werkstoff, 2006, p. $172-177$.

[24]X. Cheng, Q. Rongrong and W. Yanling, WoodThermoplastic Composites from Wood Flour and HighDensity Polyethylene, Wiley InterScience, 2009.

[25] D. Osso, O. Tillement, P. Fleurentin and J.-L. Guichard, Physico-chimie de l'interface bois polymère Rapport CST 99/001 CAP, Dombasle: Sciences \& Techniques, 1999.

[26] J. Baïlon and J. Dorlot, Des matériaux, 3e édition ed., école Polytechnique de Montréal: Presses internationales Polytechniques, 2005.

[27] Y. Seo and D. Kim, Effets of wood flour size on the physical properties of Polypropylene /Wood flour Composites, vol. 3, Polymer Korea, 2014, pp. 327-332.

[28] K. Oksman, Mechanical properties of natural fibre mat reinforced thermoplastic, App. Compos. Mater, 2000, pp. 403-414.

[29] N. Stark and A. Sanadi, Effects of fiber type on the properties of wood-plastic composites,Progress in woodfibre-plastic composites conference, Toronto: Materials and Manufacturing Ontario, 2000, p. 14.

[30]M. Salemane and A. Luyt, Thermal and mechanical properties of polypropylene-wood powder composites, Journal Applied Polymere Science, 2006, p. 4173-4180.
[31]C. Klason, J. Kubat and H. Strömvall, The efficiency of cellulosic fillers in common thermoplastics part 1 Filling without processings aids or coupling agents., Inter. J. Polymeric Mater, 1984, pp. 159-187.

[32]R. Arieby, Carcatérisation mécanique et modélistation thermodynamique du comportement anisitrope $\mathrm{du}$ polyethylene à haute densité, Nancy, France/Lorraine : Thèse doctorat de l'Institut National Polytechnique De Lorraine, Nancy-Université, 2007.

[33] D. Gardner, M. Wolcott, L. Wilson, Y. Huang and M. Carpenter, Our understanding of wood surface chemistry in 1995, Proceeding of Wood Adhesive ed., C. A.W and C. A.H, Eds., Forest Products Society, 1995.

[34]A. Alireza and N. Amir, Performance properties of microcrystalline cellulose as a reinforcing agent in wood plastic composites, Composites: Part B, 2010, p. 578-581.

[35]A. S. Singha, K. Raj and Rana, Chemically Induced Graft Copolymerization of Acrylonitrile Onto Lignocellulosic Fibers, vol. 124, Appl Polym Sci, 2012, p. 1891-1898.

[36] C. Ashish and S. K. Balbir, Synthesis Characterization and Evaluation of Novel Hibiscus sabdariffa-gpoly(EA) Copolymer, J Appl Polym Sci, 2012, p. 448454.

[37] A. Arbelaiz, B. Fernandez, A. Valea and I. Mondragon, Mechanical properties of short flax fibre bundle/poly(3caprolactone) composites: Influence of matrix modification and fibre content, Carbohydrate Polymers, 2006, p. 224-232.

[38]F. Hao, L. Jian and W. Lijuan, Preparation of biodegradable flax shive cellulose-based superabsorbent polymer under microwave irradiation, vol. 3, BioResources, 2010, pp. 1484-1495.

Volume 6 Issue 1, January 2017

www.ijsr.net

Licensed Under Creative Commons Attribution CC BY 